\title{
FIELD-APPLIED FUNGICIDES AND POSTHARVEST TREATMENTS TO CONTROL ASPARAGUS DISEASES POSING BIOSECURITY THREATS TO NEW ZEALAND
}

\author{
L-H. CHEAH and C.M. HORLOCK \\ Crop \& Food Research, Private Bag 11600, Palmerston North, New Zealand
}

Corresponding author: cheahl@crop.cri.nz

\begin{abstract}
Collaborative research between New Zealand and Australia has investigated field-applied fungicides and postharvest treatments for control of asparagus rust (caused by Puccinia asparagi) and phomopsis stem blight of asparagus (caused by Phomopsis asparagi) in Queensland. In a 2004 field trial, the fungicides difenoconazole and propiconazole reduced the incidence of asparagus rust. In a 2005 field trial, four fungicides (carbendazim, chlorothalonil, iprodione and propiconazole) reduced the severity of phomopsis stem blight. Postharvest disinfection with sodium hypochlorite or with calcium hypochlorite at $150 \mathrm{ppm}$ was highly effective at reducing $P u$. asparagi and $P h$. asparagi spore germination on water agar. Integrated disease management based on field and postharvest methods are suggested to reduce the risk of importation of the diseases to New Zealand. Similar methods could be used for controlling these diseases if they establish.
\end{abstract}

\section{INTRODUCTION}

Three diseases, asparagus rust (caused by Puccinia asparagi), phomopsis stem blight (caused by Phomopsis asparagi) and asparagus anthracnose (caused by Colletotrichum gloeosporioides), were first detected on asparagus in Queensland, Australia, in 2000, but have not been recorded on asparagus in New Zealand. Both asparagus rust and phomopsis stem blight are causing significant crop losses in Queensland (Cheah et al. 2003; Beasley et al. 2004). These two diseases have already spread to production areas in Victoria, Australia, and since they could possibly spread to New Zealand, they are a threat to New Zealand's biosecurity. With the emphasis of Biosecurity New Zealand on off-shore auditing, it is important to control or mitigate the risk of unwanted pests and diseases before they arrive at the border.

From 2002 to 2004 collaborative research has been undertaken at the Queensland Department of Primary Industry and Fisheries and Crop \& Food Research to investigate field and postharvest control of these diseases. This paper reports the results of trials of integrated control strategies based on field and postharvest methods for disease management that could be used before spears are imported into New Zealand.

\section{MATERIALS AND METHODS}

\section{Phomopsis stem blight and asparagus rust field trial - 2004 season}

A field trial to determine the effectiveness of five different fungicides, benomyl, chlorothalonil, mancozeb, difenoconazole and propiconazole (Tables 1 and 2), on phomopsis stem blight and asparagus rust was established near Warwick, Queensland, on summer regrowth of asparagus during January 2004. The field trial was carried out on established cv. Grande asparagus plants, which were approximately 10 years old.

The fungicides were prepared as per manufacturers' instructions (see Tables 1 and 2 for rates) and applied to asparagus spears once (11 days after emergence only) or twice (11 days and 18 days after emergence). Fungicides were applied using a petrol-driven 
sprayer (Cropland) through an adjustable hollow cone nozzle (20 bar) at a rate of approximately 5 litres/plot. For each treatment the fungicide was sprayed until runoff. Control plants were unsprayed. Experimental plots were $2 \mathrm{~m}$ in length, separated by $2 \mathrm{~m}$ of guard plants. Treatments were replicated four times in a randomised complete block design, with guard rows between each block.

Assessment of asparagus stems for phomopsis stem blight and asparagus rust was made 4 weeks after the second fungicide application. All stems from within the experimental plots were harvested, transported back to the laboratory and rated for disease. The number of phomopsis stem blight and asparagus rust lesions per stem was recorded and the percentage of plants with disease symptoms calculated. The severity of phomopsis stem blight lesions was also rated using the following scale: $0=$ none; $1=$ small lesions $(<0.2 \mathrm{~cm}) ; 2$ = spreading lesions; $3=$ large lesions $(>1 \mathrm{~cm}) ; 4$ = pycnidia formation (Sonoda et al. 1997).

\section{Phomopsis stem blight field trial - 2005 season}

In the second season, a trial was established on a second property near Warwick on autumn regrowth of established asparagus (cv. Atlas) plants during March 2005. The fungicide treatments (Table 2) were carbendazim, chlorothalonil, iprodione and propiconazole. These four fungicides were prepared as per manufacturers' instructions and applied to asparagus fern 4 weeks after emergence. Fungicides were applied in the same fashion as the 2004 field trial, at a rate of approximately 5 litres/experimental plot. Asparagus stems were assessed for phomopsis stem blight 4 weeks after the initial application of the fungicide treatments. The asparagus fern then received a second application of fungicide, and a final rating was performed after another 4 weeks ( 8 weeks after the initial application, 12 weeks after emergence).

\section{Postharvest disinfectants and in vitro spore germination}

Conidia of Ph. asparagi were obtained by washing 14- to 21-day-old colonies growing on PDA with sterile distilled water and dislodging the conidia with a sterile glass rod. The spores were filtered through two layers of sterile gauze, and the resultant conidium suspension was adjusted to a concentration of $1 \times 10^{6}$ conidia/ml using a haemocytometer. Puccinia asparagi urediniospores were collected from rust-affected asparagus stems, suspended in distilled water and the concentration adjusted as described above.

The spore suspensions were then mixed with each of the postharvest disinfectants, sodium hypochlorite (bleach) or calcium hypochlorite (chlorine) (at twice the desired final concentrations, 50 and $150 \mathrm{ppm}$ ) in a ratio of $5 \mathrm{ml}: 5 \mathrm{ml}$ and left to stand for $5 \mathrm{~min}$. Aliquots $(100 \mu \mathrm{l})$ of the suspensions were placed on water agar (WA) in Petri dishes using a micropipette and spread evenly with a sterile glass rod. Spore germination and germ tube elongation were determined after the Petri dishes were incubated for 48 hours at $25^{\circ} \mathrm{C}$ in darkness.

Germination percentage was determined by counting the number of germinated and non-germinated spores in a field of view at $\times 100$ magnification (ca 30 conidia). Five replicate Petri dishes and two samples (i.e. two fields of view) per Petri dish were assessed. Spores were considered germinated when the germ tube was longer than the diameter of the spore. Germ tube length was measured on 10 randomly selected spores on each of five replicate Petri dishes.

\section{RESULTS \\ Phomopsis stem blight and asparagus rust field trial - 2004 season}

None of the five fungicides tested reduced $(\mathrm{P}>0.05)$ the incidence of phomopsis stem blight compared with the untreated control. The mean for the untreated control was $26.2 \%$ and the means for treatments ranged from $20.3 \%$ to $34.3 \%$. Similarly, there was no difference $(\mathrm{P}>0.05)$ in the number of lesions per stem for any of the fungicide treatments. The mean for the untreated control was 0.9 lesions/stem and the means for treatments ranged from 0.7 to 1.9 lesions/stem. The severity of phomopsis stem blight on asparagus fern sprayed with different fungicide treatments was also not different $(\mathrm{P}>0.05)$. The mean for the untreated control was 0.7 and the means for treatments 
ranged from 0.5 to 0.9 .

Two of the fungicides tested, difenoconazole and propiconazole, reduced $(\mathrm{P}<0.05)$ the incidence of asparagus rust (Table 1). The data indicate that one application (11 days after emergence) of these fungicides was just as effective as two applications (11 and 18 days after emergence).

TABLE 1: Mean incidence (\%) of rust (Puccinia asparagi) on asparagus fern sprayed once (11 days after emergence) or twice (11 and 18 days after emergence) in the 2004 season.

\begin{tabular}{llccc}
\hline Treatment & Trade name and rate & One spray & Two sprays & Mean \\
\hline Control & - & 10.9 & - & $10.9 \mathrm{~b}^{1}$ \\
Benomyl & Benlate $(1 \mathrm{~g} \mathrm{ai} /$ litre $)$ & 17.7 & 13.0 & $15.4 \mathrm{~b}$ \\
Chlorothalonil & Bravo $(1 \mathrm{ml} \mathrm{ai} / \mathrm{litre})$ & 17.5 & 0.9 & $9.2 \mathrm{ab}$ \\
Mancozeb & Dithane $(1 \mathrm{ml} \mathrm{ai} / \mathrm{litre})$ & 8.9 & 24.2 & $16.6 \mathrm{~b}$ \\
Difenoconazole & Score $(0.25 \mathrm{ml}$ ai/litre $)$ & 0.0 & 1.3 & $0.6 \mathrm{a}$ \\
Propiconazole & Tilt $(0.25 \mathrm{ml}$ ai/litre $)$ & 1.9 & 0.0 & $0.9 \mathrm{a}$ \\
Mean & & 9.5 & 7.9 & \\
\hline
\end{tabular}

${ }^{1}$ Means followed by the same letter are not different $(\mathrm{P}=0.05)$ by ANOVA test.

\section{Phomopsis stem blight field trial - 2005 season}

Two applications of any of the fungicides significantly reduced $(\mathrm{P}<0.05)$ the number of phomopsis stem blight lesions per stem compared with the untreated control (second disease assessment in Table 2). Although not statistically significant, the incidence and severity of phomopsis stem blight was also reduced by two applications of these fungicides.

TABLE 2: Mean incidence (percentage of stems with disease), severity (0-4 scale) and number of Phomopsis asparagi lesions per stem on asparagus fern sprayed 4 weeks and 8 weeks after spear emergence in 2005.

\begin{tabular}{|c|c|c|c|c|}
\hline Treatment & Trade name and rate & Incidence (\%) & $\begin{array}{c}\text { No. lesions/ } \\
\text { stem }\end{array}$ & $\begin{array}{c}\text { Disease } \\
\text { severity }^{1}\end{array}$ \\
\hline \multicolumn{5}{|c|}{ First assessment after one spray - 4 weeks post emergence } \\
\hline Control & & $19.3 \mathrm{a}^{2}$ & $0.4 \mathrm{a}$ & $0.7 \mathrm{a}$ \\
\hline Iprodione & Rovral (0.5 ml ai/litre) & $11.7 \mathrm{a}$ & $0.3 \mathrm{a}$ & $0.4 \mathrm{a}$ \\
\hline Chlorothalonil & Bravo (1 ml ai/litre) & $7.7 \mathrm{a}$ & $0.1 \mathrm{a}$ & $0.2 \mathrm{a}$ \\
\hline Carbendazim & Spin Flo (0.5 ml ai/litre) & $13.1 \mathrm{a}$ & $0.5 \mathrm{a}$ & $0.3 \mathrm{a}$ \\
\hline Propiconazole & Tilt $(0.25 \mathrm{ml}$ ai/litre $)$ & $9.2 \mathrm{a}$ & $0.1 \mathrm{a}$ & $0.2 \mathrm{a}$ \\
\hline \multicolumn{5}{|c|}{ Second assessment after two sprays -8 weeks post emergence } \\
\hline Control & & $18.7 \mathrm{a}$ & $0.5 \mathrm{~b}$ & $0.7 \mathrm{a}$ \\
\hline Iprodione & Rovral (0.5 ml ai/litre) & $6.8 \mathrm{a}$ & $0.1 \mathrm{a}$ & $0.3 \mathrm{a}$ \\
\hline Chlorothalonil & Bravo (1 ml ai/litre) & $3.1 \mathrm{a}$ & $0.1 \mathrm{a}$ & $0.1 \mathrm{a}$ \\
\hline Carbendazim & Spin Flo (0.5 ml ai/litre) & $7.3 \mathrm{a}$ & $0.2 \mathrm{a}$ & $0.3 \mathrm{a}$ \\
\hline Propiconazole & Tilt (0.25 ml ai/litre) & $4.2 \mathrm{a}$ & $0.1 \mathrm{a}$ & $0.2 \mathrm{a}$ \\
\hline
\end{tabular}

${ }^{1}$ Subjective rating: $0=$ none; $1=$ small lesions $(<0.2 \mathrm{~cm}) ; 2=$ spreading lesions; $3=$ large lesions $(>1 \mathrm{~cm}) ; 4$ = pycnidia formation.

${ }^{2}$ Means followed by the same letter are not different $(\mathrm{P}=0.05)$ by ANOVA test. 


\section{Postharvest disinfectants and in vitro spore germination}

Exposing Phomopsis and Puccinia spores to either $150 \mathrm{ppm}$ or $50 \mathrm{ppm}$ bleach reduced spore germination and germ tube elongation compared with the untreated control (Table $3)$. There was no difference between the two bleach concentrations $(\mathrm{P}>0.05)$. Complete inhibition of germination of Phomopsis spores was observed at $150 \mathrm{ppm}$.

The germination and germ tube elongation of Phomopsis and Puccinia spores were also inhibited by exposure to $150 \mathrm{ppm}$ and $50 \mathrm{ppm}$ chlorine (Table 3). For Phomopsis spores there was no difference between $150 \mathrm{ppm}$ and $50 \mathrm{ppm}$ chlorine $(\mathrm{P}>0.05)$. However, $150 \mathrm{ppm}$ chlorine was more effective than $50 \mathrm{ppm}$ chlorine against Puccinia spores, as shown by lower spore germination and germ tube elongation (Table 3 ).

TABLE 3: Mean germination (\%) and germ tube elongation $(\mu \mathrm{m})$ of Phomopsis asparagi and Puccinia asparagi spores after treatment with bleach (sodium hypochlorite) or chlorine (calcium hypochlorite) at $50 \mathrm{ppm}$ or $150 \mathrm{ppm}$. Spores were incubated for 48 hours at $25^{\circ} \mathrm{C}$ on water agar.

\begin{tabular}{lccccc}
\hline & \multicolumn{2}{c}{ Phomopsis asparagi } & & \multicolumn{2}{c}{ Puccinia asparagi } \\
\cline { 2 - 3 } \cline { 5 - 6 } Treatment & $\begin{array}{c}\text { Germination } \\
(\%)\end{array}$ & $\begin{array}{c}\text { Germ tube } \\
\text { length }(\mu \mathrm{m})\end{array}$ & & $\begin{array}{c}\text { Germination } \\
(\%)\end{array}$ & $\begin{array}{c}\text { Germ tube } \\
\text { length }(\mu \mathrm{m})\end{array}$ \\
\hline Bleach & & & & & \\
Control & $89.1 \mathrm{a}^{1}$ & $74.0 \mathrm{a}$ & & $38.2 \mathrm{a}$ & $830.4 \mathrm{a}$ \\
$50 \mathrm{ppm}$ & $0.2 \mathrm{~b}$ & $0.2 \mathrm{~b}$ & & $3.3 \mathrm{~b}$ & $14.2 \mathrm{~b}$ \\
$150 \mathrm{ppm}$ & $0.0 \mathrm{~b}$ & $0.0 \mathrm{~b}$ & & $0.7 \mathrm{~b}$ & $1.4 \mathrm{~b}$ \\
Chlorine & & & & & \\
Control & $82.7 \mathrm{a}$ & $45.2 \mathrm{a}$ & & $62.0 \mathrm{a}$ & $692.6 \mathrm{a}$ \\
$50 \mathrm{ppm}$ & $0.2 \mathrm{~b}$ & $0.0 \mathrm{~b}$ & & $10.2 \mathrm{~b}$ & $232.0 \mathrm{~b}$ \\
$150 \mathrm{ppm}$ & $0.0 \mathrm{~b}$ & $0.0 \mathrm{~b}$ & & $0.9 \mathrm{c}$ & $8.8 \mathrm{c}$ \\
\hline
\end{tabular}

${ }^{1}$ Means followed by the same letter are not different $(\mathrm{P}=0.05)$ by ANOVA test.

\section{DISCUSSION}

Asparagus rust incidence was reduced by the fungicides difenoconazole and propiconazole in 2004. Elsewhere, mancozeb has been found effective for controlling rust (Ogawal et al. 1999) and is recommended for rust control in Washington State, USA (Elmer et al. 1996). However, mancozeb was not found to be effective in the present study. The lack of control may be due to the application technique used, rather than the inability of the fungicide to stop fungal growth (Horlock et al. 2005). The rapid growth of spears does not allow plant tissues to remain effectively covered by protectant fungicide.

The number of lesions/stem of phomopsis stem blight was reduced by 2 applications of the four fungicides (iprodione, chlorothalonil, carbendazim and propiconazole) tested in 2005. Chlorothalonil and propiconazole were also included in the 2004 trial along with the other three fungicides tested but did not show any disease control, possibly due to high variation in disease incidence between plots. Carbendazim is recommended for phomopsis stem blight control in USA (Punithalingam 1990) and the results from the present trial would agree with this.

During previous field surveys it was observed that those growers who applied difenoconazole and propiconazole on their crops had reduced incidence of asparagus rust or phomopsis stem blight (Horlock et al. 2005). The present work confirms the effectiveness of these two fungicides on asparagus rust and of propiconazole on phomopsis stem blight. It has also been noticed that crop monitoring to detect disease early allowed growers to take immediate action and apply effective fungicides before 
disease had spread further (Cheah et al. 2005).

At present, chlorine at $100 \mathrm{ppm}$ is recommended in Australia for dipping of asparagus spears before they can be transported to other states. At the request of the Australian Asparagus Council, further postharvest disinfestation experiments were performed to determine the efficacy of bleach (sodium hypochlorite) and chlorine (calcium hypochlorite) at the lower concentration of $50 \mathrm{ppm}$. Based on the results from the present experiments, it is suggested that spears should be dipped in $150 \mathrm{ppm}$ of bleach or chlorine for most effective spore kill, particularly for $\mathrm{Pu}$. asparagi.

In New Zealand difenoconazole is registered for control of stemphylium spot on asparagus. The present results indicate that difenoconazole and propiconazole and effective postharvest disinfectants (such as chlorine) could be used together for control of asparagus rust and phomopsis stem blight. It is hoped that integrated disease management using early detection of disease outbreaks, appropriate fungicide applications to crops and treatment of spears transported from affected areas, will provide a basis for management of asparagus rust and phomopsis stem blight on asparagus, prior to importation of spears or in the event that these diseases are spread to New Zealand.

\section{ACKNOWLEDGEMENTS}

The project was funded by Horticulture Australia Ltd, the Foundation for Research, Science and Technology, Dept of Natural Resources and Environment, Victoria, the NZ Asparagus Council, the Australian Asparagus Council, Sunraysia Asparagus Growers and Queensland growers. Thanks to Dr D. Beasley for carrying out field and laboratory work.

\section{REFERENCES}

Beasley D, Horlock CM, Cheah L-H 2004. Phomopsis stem blight of asparagus: field survey and fungicide screening. New Zealand Plant Protection 57: 346 (abstract only).

Cheah L-H, Horlock CM, Davis RD 2003. Field survey to assess spread of new asparagus diseases in Queensland. New Zealand Plant Protection 56: 106-108.

Cheah L-H, Horlock CM, Beasley DR 2005. Cultural methods for management of asparagus diseases. Proceedings of the 15th Australasian Plant Pathology Society Conference: 250 .

Elmer WH, Johnson DA, Mink GI 1996. Epidemiology and management of the diseases causal to asparagus decline. Plant Disease 80: 117-125.

Horlock CM, Beasley DR, Cheah L-H 2005. Control of Phomopsis stem blight of asparagus. Proceedings of the 15th Australasian Plant Pathology Society Conference: 326.

Ogawal K. Adipala E, Owera SA, Singh BP 1999. Effectiveness of climate, cultivar, and fungicide in controlling rust in asparagus. Acta Horticulturae 479: 199-203.

Punithalingam E 1990. Phomopsis asparagi. C.M.I. Descriptions of Fungi and Bacteria No. 1017. CAB International Mycological Institute, Surrey, England. 3 pp.

Sonoda T, Uragami A, Kaji K 1997. Evaluation of Asparagus officinalis cultivars for resistance to stem blight by using a novel inoculation method. HortScience 32: 1085-1086. 